\title{
Izabela Stachowiak
}

Uniwersytet im. A. Mickiewicza w Poznaniu

\section{ROLA MIĘDZYNARODOWYCH PROGRAMÓW SPOLECZNYCH W PROMOCJI JĘZYKA POLSKIEGO JAKO OBCEGO}

\section{SŁOWA KLUCZOWE: promocja języka polskiego jako obcego, akwizycja języka}

Celem niniejszego referatu jest chęć podzielenia się pewnymi spostrzeżeniami, które zrodziły się podczas analizy ankiet, dotyczących motywacji obcokrajowców do nauki języka polskiego.

Dynamika rozwoju badań nad językiem polskim jako obcym wiąże się z akcesją Polski do Unii Europejskiej. Pierwszym ważnym aspektem wiążącym się z integracją jest Ustawa z dnia 11 kwietnia 2003 roku o zmianie ustawy o języku polskim (Dz. U. Nr 73 poz. 661) wprowadzająca możliwość uzyskania przez cudzoziemców certyfikatu znajomości języka polskiego po zdaniu egzaminu przed państwową komisją egzaminacyjną. Wprowadzony system certyfikacji uplasował język polski na równi z innymi językami europejskimi, których poziom opanowania określają systemy certyfikatowe, realizowane zgodnie z zaleceniami Rady Europy zmierzającymi do standaryzacji testowania znajomości języków obcych w Europie. Równorzędnie z utworzeniem sytemu egzaminacyjnego z języka polskiego jako obcego dostrzegalny jest wzrost liczby wydawanych podręczników i zróżnicowanych materiałów dydaktycznych.

Wobec powyższych zmian związanych $\mathrm{z}$ akcesją Polski do UE, otwarciem granic, większym przepływem ludności i dążeniami do standaryzacji systemów edukacyjnych w Europie, koniecznością stało się przeprowadzenie badań nad liczbą chętnych do nauki języka polskiego jako obcego oraz nad ich motywacją.

Jest rzeczą oczywistą, iż możemy biernie analizować i kumulować odpowiedzi ankietowanych na temat ich motywacji. Ważniejszym jednak w tym momencie zagadnieniem jest opracowanie możliwości aktywnego wpływania na zwiększanie liczby osób podejmujących naukę języka polskiego, a także pytanie, w jakich obszarach życia społeczeństw międzynarodowych należy szukać potencjalnych zainteresowanych podjęciem nauki języka polskiego jako obcego.

Jeden $\mathrm{z}$ aktualnych kierunków jaki wyłania się na podstawie odpowiedzi samych cudzoziemców, to dwa główne programy: Erasmus, i co ciekawe, waż- 
niejszy w opinii samych obcokrajowców - Wolontariat międzynarodowy. Dla przykładu przytoczę kilka wybranych odpowiedzi:

Francja (L.p. 165) — Wyjazd do Polski na Erasmus, a później komunikacja ze znajomymi.

Francja (L.p. 243) - Dwa lata temu dziekan wydziału europejstyki zaproponowat mi żebym uczestniczyła $w$ wymianie studentów $w$ programie Erasmus do Krakowa. Pomyslatam, że to dobry pomyst i zdecydowałam się studiować przez sześć miesięcy w Krakowie. Lekcje były po angielsku ale chciałam lepiej mówić po polsku. Ponad to mieszkając w Krakowie, musiałam mówić z Polakami, na przyktad $w$ sklepie. To stanowiło motywacje do podjęcia nauki języka polskiego.

Niemcy (L.p. 50) - Musiałem mówić po polsku jak byłem w Krakowie między Polakami na wolontariat społeczny. Chciałem być w kontaktu z ludźmi. Chciatem poznać nowej kulturę, które byta dla mnie catkiem nieznana.

Program Erasmsus został zainicjowany przez Komisję Europejską w 1987 r. Powstał on z myślą o zwiększeniu mobilności studentów i wykładowców, a także poprawieniu jakości kształcenia w uniwersytetach. Ponadto program zakładał, iż dzięki takiej mobilizacji Unia Europejska będzie dysponować personelem znającym praktykę życia społecznego i gospodarczego innych państw członkowskich oraz posiadającym lepsze kompetencjelingwistyczneniezbędne do rozwijania współpracyw sektorach społecznogospodarczych Unii Europejskiej, zwiększając tym samym jej konkurencyjność na rynku światowym [Rabczuk, 2007, s.16]. Program Erasmus umożliwia studiowanie, bądź prowadzenie wykładów, przez kilka miesięcy na uniwersytecie w innym kraju europejskim. W początkowym okresie tylko 11 państw wzięło udział w tym projekcie: Belgia, Dania, Niemcy, Grecja, Hiszpania, Francja, Irlandia, Włochy, Holandia, Portugalia i Zjednoczone Królestwo. W roku akademickim 1998/1999 do programu dołączyła też Polska [Kaczmarek, Wciórka, 2011, s.11].

Odnotowano, iż zainteresowanie udziałem w programie Erasmus zdecydowanie wzrosło po przyjęciu w 2004 r. do Unii Europejskiej nowych członków. Obecnie uczestniczą w nim 33 państwa: 27 państw członkowskich Unii Europejskiej, 4 państwa Obszaru Gospodarczego: Islandia, Lichtenstein, Norwegia i Szwajcaria oraz kraje kandydujące: Chorwacja i Turcja [www.erasmus.org.].

Jak już wcześniej zostało wspomniane, dzięki programowi Erasmus powstają bardziej sprzyjające warunki do nauki języków obcych, a w szczególności języków mniej rozpowszechnionych. Dowodem na to są uzyskane odpowiedzi ankietowanych z Francji, którzy wziąwszy udział w tym programie, postanowili kontynuować naukę języka polskiego rozpoczętą w trakcie studiowania w Polsce. Należy jednak zwrócić uwagę, iż promowany program Erasmus jest zaledwie częścią ogółu projektów edukacyjnych, które mają wesprzeć osiągnięcie celów polityczno-ekonomicznych założonych przez Unię Europejską.

Drugim istotnym wydarzeniem w kształtowaniu długoletnich planów edukacyjnych w Europie było opublikowanie przez Komisję Europejską w połowie lat 90-tych tzw. Biatej i Niebieskiej ksieggi Komisji Europejskiej. 
Treści Białej księgi dotyczą głównie organizacji systemów oświatowych i koncentrują się na:

- kulturze ogólnej,

- rozwoju przydatności do zatrudniania i zdolności do aktywności ekonomicznej, w postaci akumulacji wiedzy podstawowej, wiedzy technicznej i umiejętności społecznych ${ }^{1}$.

Z kolei raporty zawarte w Niebieskiej księdze dotyczyły czterech kierunków zmian w organizacji narodowych systemów oświatowych:

- budowania europejskiego obywatelstwa;

- wzmocnienia europejskiej konkurencyjności i zabezpieczenia zatrudnienia;

- utrzymania społecznej więzi;

- pełnego wykorzystywania możliwości stwarzanych przez techniki informatyczne ${ }^{2}$.

Przedsięwzięcia te zostały zaktualizowane w listopadzie 2001 r., kiedy to Komisja Europejska ogłosiła komunikat $W$ kierunku urzeczywistnienia wizji Europy jako obszaru kształcenia ustawicznego [Syrek, 2007].

Ogólnie rzecz ujmując, koncepcja edukacji permanentnej (ang. lifelong education) a wraz z nią uczenia się przez całe życie (ang. lifelong learnig) realizuje zadania podnoszenia poziomu wiedzy, umiejętności i kompetencji społeczeństwa w zakresie rozwoju osobistego oraz społecznego. Dodatkowo ma za zadanie wspierać wzrost możliwości zatrudnienia i adaptacji do zmieniających się warunków rynku pracy.

Należy jednak pamiętać, iż w kształtowanym współcześnie świecie, gdzie promuje się wielokulturowość, wieloetniczność, wielowyznaniowość generują się nowe problemy jak np. bezrobocie, rasizm itp. [por. Woźniak, Niedbała, 2004, s. 90]. Anthony Giddens przestrzega, iż skutki globalizacji są dalekosiężne i dotyczą praktycznie wszystkich aspektów świata społecznego. Globalizacja jest procesem otwartym i uwikłanym w wewnętrzne sprzeczności, a zatem trudno przewidzieć i kontrolować jej przebieg. Zdaniem Bożeny Wojtasik skutki globalizacji najsilniej można zaobserwować wśród młodzieży, która dopiero próbuje kształtować swoją tożsamość i szukać swojej drogi zawodowej, gdyż:

Realia świata współczesnego, niepewność jutra, nieprzejrzystość, nietrwałość, powodują, że zwiększone ryzyko towarzyszy też wielu decyzjom, które zostają podejmowane. A zatem wszelakiego rodzaju decyzje, są ryzykowne, bo w warunkach szybkich zmian w gospodarce

${ }^{1}$ Matuszewska, Wolontariat międzynarodowy jako forma aktywności edukacyjnej młodzieży, Olsztyn, 2010, s. 19.

2 Tamże, s. 20. 
trudno jest cokolwiek przewidzieć i zaplanować. W szczególnie trudnej sytuacji jest młodzież, która wielokrotnie musi dokonywać wyborów edukacyjno-zawodowych, nie będąc do nich przygotowana.

[Wojtasik, 2005, s. 177]

Socjolodzy podkreślają, iż w społeczeństwie ryzyka zaciera się dotychczasowy model pracy. Częściej jest dostępna praca w niepełnym wymiarze godzin, kontrakt lub część etatu. Trudno też przewidzieć, jakie zawody i jakie kwalifikacje będą poszukiwane i czy będzie można znaleźć zatrudnienie. Podkreślają, iż będzie coraz większe zapotrzebowanie na elastycznych pracowników, którzy będą posiadali szereg rozmaitych umiejętności zawodowych, po kilka zawodów i będą mogli pracować na różnych stanowiskach. Nastanie system portfolio — ludzi z teczką pełną kwalifikacji, łatwo zmieniających pracę [Wojtasik, 2005, s.180].

Aby sprostać temu zadaniu i przygotować społeczeństwa na takie warunki życia, promuje się zatem idee uczenia się przez całe życie, które mają być realizowane zarówno przez edukację formalną jak i nieformalną. Przez pojęcie edukacji formalnej rozumie się powszechnie proces nauczania i uczenia się w szkołach lub uczelniach, przebiegający etapowo przez poszczególne szczeble edukacji wyznaczane przez system edukacji. Natomiast edukacja nieformalna to każda zorganizowana aktywność edukacyjna, która zachodzi poza formalnym systemem szkolnym [Matuszewska, 2010, s. 26].

Korzyści płynące z edukacji nieformalnej, traktowanej jako doskonałe uzupełnienie edukacji formalnej, zostały zaakcentowane w strategii edukacyjnej Komisji Europejskiej, która we wspomnianej wcześniej Białej księdze wskazuje, np. wolontariat międzynarodowy jako istotne miejsce w przestrzeni edukacji nieformalnej:

Wolontariat dostarcza młodym ludziom możliwości socjalizacyjnych, podczas gdy społeczeństwo również odnosi korzyści z tej niezarobkowej działalności, (...) jest zarówno formą udziału w życiu społecznym, jak i doświadczeniem edukacyjnym. Stanowi on czynnik integracji społecznej oraz bardzo skuteczny sposób zwalczania uprzedzeń. Ma charakter uniwersalny i musi pozostać dostępny dla każdego. (...) Stanowi on ważny element tworzenia wspólnej tożsamości europejskiej i powinien być wykorzystywany jako skuteczne narzędzie integracji społecznej w momencie wstąpienia nowych krajów do UE.

[Tamże, s.70]

Program wolontariatu międzynarodowego został przygotowany przez Komisję Europejską na kanwie wcześniej istniejących projektów związanych z wymianami młodzieżowymi w Europie. Były to Młodzież dla Europy (Youth for Europe w latach 1988-1991) i Młodzież dla Europy II (Youth for Europe II w latach 1991-1999). Na ich podstawie przygotowany został kolejny projekt — Wolontariat Europejski (European Volutary Service), który funkcjonuje od 1998 roku. Aktualnie realizowany jest projekt Wolontariat Europejski, Akcja 2 (European Voluntary Service, Action 2). Program ten jest kontynuowany od 2007 roku przez kolejne siedem lat pod nazwą Młodzież w Działaniu (Youth in Action) [Tamże, s. 73]. 
Wielu badaczy podkreśla znaczenie interakcji społecznych u młodych ludzi uaktywniając pewne formy zachowań, prowadzą tym samym do ukształtowania się zróżnicowanych rodzajów ,ja" i stanowią podstawę kształtowania globalnego obrazu samego siebie oraz swojej tożsamości.

Analizując motywy działań prospołecznych, Janusz Reykowski podkreśla natomiast złożoność czynników motywacyjnych, powodujących liczne spory między badaczami. Niektórzy jak M. Gliselin reprezentują pogląd, iż człowiek rodzi się i całe życie jest egoistą: Podrap altruistę i patrz, jak krwawi hipokryta. Z kolei jak podkreśla Reykowski, zauważono jednak, iż w określonych warunkach korzyść cudza nie odróżniona od własnej powoduje, iż dobro cudze staje się celem działalności, a nie środkiem dla osiągnięcia dobra własnego [Tamże, s.193].

Moim zdaniem, w tym aspekcie należałoby dodatkowo rozpatrywać motywację do wzięcia udziału w wolontariacie. $Z$ jednej strony, angażujące się osoby chcą być potrzebne i pożyteczne, a z drugiej sprawdzić siebie, wzmocnić swoje poczucie tożsamości, czy zwyczajnie nabyć doświadczenie zawodowe. Ponadto wolontariat międzynarodowy jest postrzegany i wykorzystywany przez młodzież jako możliwość zyskania czasu w obliczu konieczności podjęcia decyzji o kierunku dalszego kształcenia. Po ukończeniu szkoły średniej, zdanym egzaminie dojrzałości, ukończeniu pierwszego stopnia studiów - wcale nie czują się dojrzali, pewni i świadomi tego, co chcą robić dalej. Oczekują, iż wolontariat pomoże im znaleźć nowy pomysł na życie.

Warto też zauważyć, iż wolontariat w przekonaniu samych zainteresowanych, jest ceniony wyżej niż inne programy o charakterze edukacyjnym, czego dowodzi relacja jednej z uczestniczek takiego projektu:

W moim przypadku to było zupełnie inaczej niż u innych. Erasmus był taki bardziej... no to były studia, ale trochę nie takie prawdziwe studia. No tak, bardzo mi się podobało na Erasmusie, poznałam różnych ludzi, ale nie... Ok, nauczyłam się tam, jak żyć samemu, nauczyłam się wielu różnych rzeczy, jak to jest być za granicą, nauczyłam się języków. Ale tutaj poczułam się pożyteczna, czułam, że mogę coś zrobić. Czułam, że coś robię, zrobiłam wiele rzeczy i naprawdę lubiłam to, lubiłam organizować to wszystko.

[Matuszewska 2010, s.120]

Biorąc pod uwagę powyższe okoliczności, warto zatem w działaniach promocyjnych na rzecz popularyzacji języka polskiego wśród obcokrajowców uwzględnić olbrzymi potencjał istniejący wśród młodzieży, która nie ma jeszcze zobowiązań dorosłego człowieka, a która szuka dopiero swojej drogi.

Wiele z tych osób być może nie bierze nawet pod uwagę możliwości podjęcia nauki języka polskiego, co jednak nie znaczy, iż udział w takim wolontariacie nie może spowodować zmiany wyboru zawodu czy celów edukacyjnych czego najlepszym dowodem jest inna wolontariuszka, zafascynowana podróżowaniem i zainteresowana krajami postkomunistycznymi: 
[...] Na początku myślałam o tym, żeby wyjechać do Czech, nie myślałam o Polsce. Ale wówczas, kiedy zobaczyłam ten projekt Art \& partnership for children and youth w domu kultury... naprawdę bardzo, bardzo mi się spodobał.

[Tamże, s. 114]

Co więcej, spora grupa osób decyduje się na udział w wolontariacie jedynie z chęci zmiany środowiska, zupełnie nie uwzględniając konieczności podjęcia nauki języka. Priorytet ten ulega ewaluacji dopiero pod wpływem okoliczności:

W pierwszym tygodniu zorientowałam się [...], że przede wszystkim, najważniejsze jest żebym szybko nauczyła się języka polskiego. To dlatego, że jeżeli pracujesz w muzeum, musisz rozmawiać z ludźmi, musisz ich oprowadzać, kierować. No i musisz odpowiadać na choćby takie proste pytania jak: Gdzie jest toaleta? i tym podobne. I ja musiałam umieć im odpowiedzieć.

[Tamże, s.141]

Podsumowując, chciałabym zwrócić uwagę na to, iż przygotowując wszelkiego rodzaju programy promocji na rzecz języka i kultury polskiej, warto wykorzystać potencjał istniejący wśród młodzieży i studentów zainteresowanych udziałem W wolontariacie międzynarodowym. W dobie kryzysu ekonomicznego, bezrobocia w Europie i na świecie, młodzi ludzie nie mają czasu na hobbystyczne studiowanie języków niszowych, za jaki można uznać język polski, niemniej jednak, możliwość przyjazdu do Polski na wolontariat połączony z możliwością podjęcia kursu języka polskiego może być dla wielu z nich atrakcyjny i bardzo motywujący.

\section{Bibliografia}

Europejski Program Erasmus na Uniwersytecie im. Adama Mickiewicza w Poznaniu w latach 1998-2010, 2011, pod red. Kaczmarek T., Wciórka J., Poznań.

Matuszewska A., 2010, Wolontariat międzynarodowy jako forma aktywności edukacyjnej młodzieży, Olsztyn.

RABCZUK W., 2007, Europejskie spektrum edukacji — program Erasmus [w:] Europejski wymiar edukacji w świetle projektu OBSER-Erasmus, Łopaciński M., Szczurkowska M. (red.), Warszawa, s. 15-25.

ReYkowski J., 1986, Motywacja, postawy prospołeczne, a osobowość, Warszawa.

Syrek E., 2007, Polityka edukacyjna w Unii Europejskiej - Programy wspólnotowe: Sokrates, Leonardo da Vinci [w:] Europejski wymiar edukacji $w$ świetle projektu OBSER-Erasmus, Łopaciński M., Szczurkowska M. (red.), Warszawa, s. 34-45.

WoJTAsiK B., 2005, Edukacyjno-zawodowe wybory nastolatków w ,społeczeństwie ryzyka” [w:] Młodzież wobec (nie)gościnnej przyszłości, Leppert R., Melosik Z., Wojtasik B. (red.), Wrocław, s. 19-25.

WoźNiaK R., NiedBąA K., 2004, Aspekty edukacji w warunkach globalizacji społecznej [w:] Edukacja wobec integracji europejskiej, Kojkoł J., Przybysz P. (red.), Gdynia. 